\title{
Blend of natural coagulants as a sustainable solution for challenges of pollution from aquaculture wastewater
}

\author{
Manoj Kumar Karnena ${ }^{1} \cdot$ Madhavi Konni $^{2} \cdot$ Bhavya Kavitha Dwarapureddi $^{1}$ - Vara Saritha $^{1}$ (D
}

Received: 21 June 2021 / Accepted: 16 September 2021 / Published online: 11 February 2022

(c) The Author(s) 2022

\begin{abstract}
Dependency on sea food has increased owing to its nutrition as well as being complete food. As the production of seafood is enhanced through aquaculture, wastewater release has also improved. The composition of wastewater from aquaculture production has been a concern as it has oil and grease, organic content, etc., which makes its treatment challenging. The present study aims at treating aquaculture wastewater using two natural coagulants-chitin and seeds of Moringa oleifera. The efficiency of the natural coagulants was compared against inorganic chemical coagulant ferric chloride. A blended coagulant with two natural coagulants seeds of Moringa oleifera and chitin was also tested. Jar test apparatus was used in the current experiments, and four coagulant doses were tested against $3 \mathrm{pH}$ ranges, from 6 to 8 . The study results showed that the coagulants showed a 30-50\% reduction in various physicochemical parameters. Further, the most promising result was obtained with the blended coagulants (di-blend) with 70-81\% removal of total nitrogen and total phosphorus and the highest reduction of chloride with $95 \%$. The Fourier-transform infrared spectroscopy showed functionalized groups responsible for coagulation, and X-ray powder diffraction analysis of the blended coagulant indicated the crystallinity and amorphous nature of the compounds. Scanning electron microscope analysis presented a firm and dense structure indicating adsorption of impurities onto the coagulant. Thus, it is evident that natural coagulants can be the solution for the challenges of aquaculture wastewater and specifically the di-blend used in the present is ascertained to be a promising solution.
\end{abstract}

Keywords Chitin $\cdot$ Ferric chloride $\cdot$ Moringa oleifera $\cdot$ Blended coagulant

\section{Introduction}

Rearing aquatic animals and plants is understood as aquaculture, ranging from fish cultivation in naturally formed ponds of rural zones to intensified complex commercial fish culture tanks of fiberglass. On a global scale, it is seen that there was a rapid growth in aquaculture. The production of aquaculture enhanced to more than 50 million presently against its production less than a million during 1950. Further, aquaculture production at a global scale grew at $8-14 \%$ per annum

\section{Manoj Kumar Karnena}

manojkumarenviron@gmail.com

$\triangle$ Vara Saritha vsjr08@gmail.com

1 Department of Environmental Science, GITAM Institute of Science, GITAM (Deemed to be University), Visakhapatnam, India

2 Department of Basic Sciences and Humanities, DADI Institute of Engineering and Technology, Visakhapatnam, India compared to only $1.5 \%$ of fish captures. It is estimated that the growth of aquaculture will reach 109 million tonnes by 2030, accounting for a $37 \%$ increase compared to 2016 . Fisheries and its allied resources encapsulate a wide variety of food sources feeding a more significant portion of the population globally, apart from the magnificent employment sector (Zhou 2017; Joseph et al. 2021; Rotter et al. 2021).

With this tremendous increase in production, equal amounts of wastewaters are also generated from this sector. Concern over the wastewaters generated is due to its characteristics of having high organic content, oil, and grease, and salts that make their treatment challenging (Dhanke et al. 2019). These characteristics call for the mandatory treatment of these wastewaters toward maintaining quality and acceptability. Several treatment methods were developed and adopted for improving water quality, reducing water usage but were differed owing to fluctuating levels of success. On the other hand, water shortages, land costs, stringent enhanced regulations have made it necessary to develop an efficient, improved treatment method. Studies have stated that the discharges from aquaculture possess greater concentrations of ammonia and 
$\mathrm{PO}_{4}{ }^{3-}$ along with pathogens (Lin et al. 2003; Yerlikaya et al. 2021). Ammonia is toxic to fish, which is limited to only $2 \mathrm{mg} / \mathrm{L}$ in aquaculture wastewaters. Still, it is generally found at a higher concentration, while enhanced concentrations of $\mathrm{PO}_{4}{ }^{3-}$ result in the rapid growth of unwanted macrophytes and algae, leading to eutrophication (Ngatia et al. 2019; Karnena and Saritha 2020; Alishahi and Aïder 2012).

Although progress toward treatment processes for phosphorus reduction is made, many efforts and research are required toward efficient treatment. It is also to be noted that much phosphate concentration exists in settleable and colloidal associated solids fractions. Hence, treatment systems that effectively remove solids are needed to be made (Sitek 2020). Conventional treatment processes for aquaculture wastewater are not feasible due to the generation of toxic residue, capital investment, and operational expertise requirements. Coagulation is understood to be the most accepted treatment for the removal of colloidal particles.

Further, coagulants can also remove the suspended mineral particles as well as reduce turbidity. Previous studies have shown that conventional coagulants such as alum and ferric chloride can inactivate and precipitate inorganic phosphorus from aquaculture pond water. Though these coagulants effectively removed pollutant load, the residual aluminum had toxic effects on plants (Yang et al. 2016; Kritchenkov et al. 2021). Consequently, coagulants having properties such as being efficient, economical, non-toxic, environment friendly, and sustainable are constantly being searched. Natural coagulants are understood to satisfy all the above-said criteria.

Earlier studies have demonstrated the usefulness of natural coagulants such as chitosan (Chung et al. 2003; Yang et al. 2016). But studies on optimization and efficacy estimation concerning conventional coagulants are meager. In these lines, the aims of the present study are twofold to evaluate the competence of natural coagulant Moringa oleifera for treating aquaculture wastewater and to compare its efficiency with conventional ferric chloride. Further, the second aim is to assess the efficacy of blended coagulant $M$. oleifera and chitin in treating aquaculture wastewater.

\section{Materials and methods}

\section{Acquiring and preparing coagulants}

Coagulants chitin and ferric chloride were of analytical grade supplied by Coastal Enterprises of company SigmaAldrich, and Merck chemicals were used in the study. Seeds of Moringa oleifera were procured from the local market, cleansed and made to powder, and sieved using a $0.25-\mu$ sieve to get a uniform size. The powder was stored in sealed polythene for further use.

\section{Effluent sample collection}

The aquaculture effluent was collected from the aquafarms located around 3-4 km from GITAM (Deemed to be University) using three $25 \mathrm{~L}$ jerry cans and filled to the brim to expel entrapped air within the can. The jerry-can was then corked, sealed, and refrigerated until the commencement of the experiment. Effluents were characterized as per the standard methods of APHA (APHA, AWWA, WEF 2012). All experiments were carried out in the laboratory of the Department of Environmental Science.

\section{Jar test experiments}

Experiments to determine the efficiency of coagulants were performed using conventional Jar test Apparatus (Cintex Flocculator). The experiments were carried out in batches and in triplicates which were represented as average. The individual jar was added with a $2 \mathrm{~L}$ sample after recording the initial temperature and adding various coagulant doses. Initial rotation of the baffles was set to $100 \mathrm{rpm}$ for flash mixing for about $2 \mathrm{~min}$, and the then slow mix was adopted at an rpm of 20 for about 30 min followed by settling of $30 \mathrm{~min}$ after the baffles are removed.

\section{Analytical procedures}

All the physicochemical analyses of all the samples are analyzed by using APHA, 2016 standard methods.

\section{Turbidity}

The nephelometric turbid meter was calibrated using 40NTU standard suspension. The sample under test is shaken thoroughly and filled in the cuvette, placed in the sample chamber. Constant value is noted down.

\section{$\mathrm{pH}$}

$\mathrm{pH}$ was measured using a $\mathrm{pH}$ meter. Calibration of electrodes was carried out using 4.0 and 9.2. After rinsing with distilled water and wiping with tissue paper, the electrode is dipped into the water sample under test. At constant value, the reading is noted down.

\section{Electrical conductivity (EC)}

The conductivity cell was calibrated with $0.1 \mathrm{~N} \mathrm{KCl}$ standard solution having a conductivity of 14.12 mmhos. After rinsing electrodes thoroughly using deionized water and wiping dry, the electrode is dipped into the sample under test. At constant value, the reading is noted down. 


\section{Total dissolved solids (TDS)}

TDS were measured gravimetrically; a clean porcelain dish's initial weight (A) was taken after igniting in a muffle furnace, partial cooling in the air, and cooling in a desiccator. Into this was added $100 \mathrm{~mL}(\mathrm{~V})$ of filtered sample and was evaporated at $100{ }^{\circ} \mathrm{C}$; on a water bath, it was dried in an oven at $103{ }^{\circ} \mathrm{C}$ for about an hour. The final weight (B) of the dried dish was taken after cooling in a desiccator.

Calculations: Total dissolved solids $(\mathrm{mg} / \mathrm{L})$

$$
=\frac{(A-B) \times 1000}{\text { Volume of Sample taken }}
$$

\section{Chlorides}

A $100 \mathrm{~mL}$ sample was taken to a flask, and an indicator potassium chromate of 2 drops was added, after which the sample turns yellow color. This solution was titrated against $0.0141 \mathrm{~N} \mathrm{AgNO}_{3}$ until the color changes to brick red. The consumed volume of $\mathrm{AgNO}_{3}$ was noted down (A). A blank was titrated; similarly, the volume of $\mathrm{AgNO}_{3}$ consumed was noted down (B)

Calculation: Chloride (mg/L)

$$
=\frac{(A-B) \times \text { Normality of } \mathrm{AgNO}_{3} \times 35.46 \times 1000}{\text { Volume of Sample taken }}
$$

\section{Total hardness}

Hundred milliliters of sample was taken into conical flask to which a buffer of $2 \mathrm{~mL}$ was added, followed by inhibitor of $1 \mathrm{~mL}$ and a pinch of Eriochrome black T indicator; solution was turned into wine-red color immediately. Solutions were titrated against $0.01 \mathrm{M}$ EDTA till the color changes to blue. A blank is also titrated similarly, and the volume of EDTA consumed both for sample (A) and blank (B) is noted down.

Calculation: Total hardness (mg/l) as $\mathrm{CaCO}_{3}$

$$
=\frac{(A-B) \times 1000}{\text { Volume of Sample taken }}
$$

\section{Calcium hardness}

Hundred milliliters of sample was taken in a conical flask to which $\mathrm{NaOH}$ solution of $1 \mathrm{~mL}$ was added, followed by a pinch of murexide indicator; solution turns to pink color. Later it was titrated against 0.01 M EDTA solution till the color changes to purple. A blank is also titrated similarly, and the volume of EDTA consumed both for sample (A) and blank (B) is noted down.
Table 1 Initial parameters of aquaculture waters

\begin{tabular}{lll}
\hline Parameters & Values & SD \\
\hline Turbidity (NTU) & 2.3 & 0.1 \\
$\mathrm{pH}$ & 8.33 & 0.1 \\
$\mathrm{EC}(\mu \mathrm{S})$ & 9.2 & 0.1 \\
TDS $(\mathrm{mg} / \mathrm{L})$ & 4157 & 1.5 \\
Chlorides (mg/L) & 25,000 & 0.1 \\
Total hardness (mg/L) & 23,000 & 2.1 \\
Calcium hardness(mg/L) & 15,000 & 0.5 \\
Total phosphorus (mg/L-P) & 11 & 0.1 \\
Total nitrogen $(\mathrm{mg} / \mathrm{L}-\mathrm{N})$ & 9.6 & 0.1 \\
\hline
\end{tabular}

Calculation: Calcium hardness $(\mathrm{mg} / \mathrm{l})$ as $\mathrm{CaCO}_{3}$

$$
=\frac{(A-B) \times 1000}{\text { Volume of Sample taken }}
$$

\section{Total nitrogen and total phosphorous}

TN was determined using a TOC-TN analyzer (SHIMADZU, Japan), and TP was established using Hach Lange cuvette tests on the spectrophotometer (DR2000, Lange GmbH Germany).

\section{Characterization of samples}

The FTIR was analyzed using the morphology of the synthesized material examined by the Philips made CM-200. XRD patterns were determined by "PANALYTICAL X'PertPro Powder X-ray diffractometer" having a graphite monochromatic $\mathrm{Cu} \mathrm{K \alpha}\left(\lambda=1.5406^{\circ} \mathrm{A}\right)$, and sample morphology was examined with a scanning electron microscope using the FEI quanta model, JSM 7600.

\section{Results}

The efficiency of natural coagulants to treat aquaculture wastewater was investigated in the present study. The results are presented as follows.

Table 1 presents the initial analysis (raw water) of aquaculture wastewater. Values are presented as the mean of 12 samples. $\mathrm{pH}$ was found to be 8.33 . Turbidity was found to be 2.3 NTU. The electrical conductivity of the initial analysis was found to be $9.2 \mu$ siemens $/ \mathrm{cm}^{2}$.

The total dissolved solids concentration was $4157 \mathrm{mg} / \mathrm{L}$. The chloride content of the samples was found to be $25,000 \mathrm{mg} / \mathrm{L}$. Concentration of total hardness was $23,000 \mathrm{mg} / \mathrm{L}$, and that of calcium hardness was $15,000 \mathrm{mg} / \mathrm{L}$. The concentrations of total phosphorous and total nitrogen were $11.6 \mathrm{mg} / \mathrm{L}$ and $9.6 \mathrm{mg} / \mathrm{L}$. 
Table 2 depicts the reduction of physicochemical parameters of the aquaculture water after treatment with ferric chloride. Turbidity reduction was observed maximum of $86.96 \%$ at $\mathrm{pH} 7$ with a dose of $0.15 \mathrm{~g} / \mathrm{L}$. Reduction in electrical conductivity was observed to be good at $\mathrm{pH} 8$ with around $99 \%$ removal. Reduction of total solids was noted to be $52-55 \%$ in all $\mathrm{pH}$ and dose ranges. Chloride reduction was observed to be a maximum of $36.46 \%$ at $\mathrm{pH} 6$ with a dose of $0.1 \mathrm{~g} / \mathrm{L}$. Total hardness removal was negative, going to a maximum of $20.14 \%$ at $\mathrm{pH} 7$ with $0.1 \mathrm{~g} / \mathrm{L}$, while calcium hardness was maximum with $69 \%$ in most doses and $\mathrm{pH}$ ranges. Total nitrogen removal was $30.43 \%$ at $\mathrm{pH} 7$ with $0.15 \mathrm{~g} / \mathrm{L}$, whereas phosphorous removal was $26.36 \%$.

Table 3 depicts the reduction of aquaculture water physicochemical parameters after chitin treatment. Turbidity reduction was observed maximum of $78.2 \%$ at $\mathrm{pH} 8$ with a dose of $0.05 \mathrm{~g} / \mathrm{L}$. Reduction in electrical conductivity was observed to be poor at $\mathrm{pH} 6 ; 12 \%$ maximum removal was found to be removal. Chloride reduction was observed to be a maximum of $84.38 \%$ at $\mathrm{pH} 7$ with a dose of $0.2 \mathrm{~g} / \mathrm{Ll}$. Total hardness removal was going to a maximum of $69.23 \%$ at pH 6 with $0.1 \mathrm{~g} / \mathrm{L}$, while calcium hardness was maximum at $78.95 \%$ at $\mathrm{pH} 7$ with $0.1 \mathrm{~g} / \mathrm{L}$. Total nitrogen removal was maximum of $53.04 \%$ at $\mathrm{pH} 7$ with $0.2 \mathrm{~g} / \mathrm{L}$, and phosphorous removal was $62.72 \%$ at $\mathrm{pH} 8$ with $0.05 \mathrm{~g} / \mathrm{L}$.

Table 4 depicts the reduction of the aquaculture water physicochemical parameters after treatment with seeds of Moringa oleifera. Turbidity reduction was observed maximum of $47.83 \%$ at $\mathrm{pH} 8$ with a dose of $0.2 \mathrm{~g} / \mathrm{L}$. Reduction in electrical conductivity was observed to be good at $\mathrm{pH} 8$ with around $5.7 \%$ removal. The decrease in total solids was negative in all $\mathrm{pH}$ and dose ranges. Chloride reduction was observed to be a maximum of $92.71 \%$ at $\mathrm{pH} 7$ with a dose of $0.05 \mathrm{~g} / \mathrm{L}$. Total hardness removal was negative in all $\mathrm{pH}$
Table 2 Percentage reduction in physicochemical parameters after treating with ferric chloride

Table 3 Reduction percentage in physicochemical parameters after treating with chitin

\begin{tabular}{llrrlrllll}
\hline pH & Dose & Turbidity & EC & $\begin{array}{l}\text { Total } \\
\text { dissolved } \\
\text { solids }\end{array}$ & Chlorides & Total hardness & Calcium hardness & TN & TP \\
\hline 6 & 0.05 & 26.09 & 10.65 & 52.61 & 28.13 & -15.79 & 61.54 & 18.26 & 16.36 \\
& 0.1 & 78.26 & 13.50 & 52.85 & 36.46 & -10.53 & 69.23 & 22.60 & 19.09 \\
& 0.15 & 56.52 & 2.05 & 52.37 & 16.67 & -42.11 & 61.54 & 26.95 & 17.27 \\
& 0.2 & 82.61 & -4.79 & 52.13 & 17.71 & -10.53 & 53.85 & 29.56 & 20.10 \\
7 & 0.05 & 8.70 & 28.94 & 54.05 & 18.75 & 0.00 & 61.54 & 29.56 & 26.36 \\
& 0.1 & 65.22 & 32.93 & 53.33 & 21.88 & 21.05 & 61.54 & 26.95 & 25.45 \\
& 0.15 & 86.96 & 33.67 & 53.57 & 27.08 & 0.00 & 69.23 & 30.43 & 26.36 \\
& 0.2 & 56.52 & 28.18 & 53.81 & 32.29 & 10.53 & 61.54 & 30.41 & 17.27 \\
8 & 0.05 & -17.39 & 99.81 & 55.98 & 15.63 & -10.53 & 61.54 & 29.56 & 25.45 \\
& 0.1 & 43.48 & 99.81 & 55.26 & -5.21 & -10.53 & 69.23 & 27.82 & 28.18 \\
& 0.15 & 34.78 & 99.81 & 55.02 & 7.29 & -42.11 & 53.85 & 26.95 & 20.9 \\
& 0.2 & 52.17 & 99.81 & 54.53 & 18.75 & -26.32 & 69.23 & 27.82 & 21.81 \\
\hline
\end{tabular}

\begin{tabular}{lllccccccl}
\hline pH & Dose & Turbidity & EC & $\begin{array}{l}\text { Total } \\
\text { dissolved } \\
\text { solids }\end{array}$ & Chlorides & Total hardness & Calcium hardness & TN & TP \\
\hline 6 & 0.05 & 69.5 & 12.06 & 2.67 & 78.13 & 73.68 & 69.23 & 31.3 & 27.27 \\
& 0.1 & 60.86 & 11.08 & -0.86 & 80.21 & 42.11 & 53.85 & 35.65 & 41.81 \\
& 0.15 & 65.21 & -3.2 & -14.5 & 84.36 & 63.16 & 46.15 & 37.39 & 45.45 \\
& 0.2 & 56.52 & -0.32 & -11.54 & 83.33 & 47.37 & 53.85 & 40 & 51.81 \\
7 & 0.05 & 60.86 & 4.34 & -5.94 & 82.29 & 78.95 & 46.15 & 41.73 & 54.54 \\
& 0.1 & 60.86 & 6.52 & -4.64 & 83.33 & 68.42 & 46.15 & 49.56 & 60 \\
& 0.15 & 60.86 & 5.43 & -3.8 & 83.33 & 84.21 & 61.54 & 46.95 & 60.9 \\
& 0.2 & 56.52 & 2.17 & -9.26 & 84.38 & 84.21 & 61.54 & 53.04 & 62.71 \\
8 & 0.05 & 78.2 & -3.26 & -14.52 & 80.21 & 26.32 & 46.15 & 46.95 & 62.72 \\
& 0.1 & 60.86 & -1.08 & -13.01 & 80.21 & 63.16 & 53.85 & 45.21 & 58.18 \\
& 0.15 & 69.5 & 9.7 & -0.86 & 83.33 & 42.11 & 69.21 & 48.69 & 60.9 \\
0.2 & 73.91 & 1.08 & -10.07 & 80.21 & 42.11 & 69.20 & 49.56 & 64.54 \\
\hline
\end{tabular}


and dose ranges, while calcium hardness was maximum with $84.62 \%$ at $\mathrm{pH} 7$ with amounts 0.1 and $0.2 \mathrm{~g} / \mathrm{L}$. Total nitrogen removal was maximum of $50.43 \%$ at $\mathrm{pH} 8$ with $0.2 \mathrm{~g} / \mathrm{L}$, and phosphorous removal was $69.09 \%$ at $\mathrm{pH} 8$ with $0.1 \mathrm{~g} / \mathrm{L}$.

Table 5 depicts the reduction of the aquaculture water physicochemical parameters after treatment with a blend of seeds of Moringa oleifera and chitin. Turbidity reduction was observed maximum of $56.52 \%$ at $\mathrm{pH} 8$ with a dose of $0.05 \mathrm{~g} / \mathrm{L}$. Electrical conductivity reduction was observed to be good at $\mathrm{pH} 8$ with around $64.49 \%$ and dose $0.1 \mathrm{~g} / \mathrm{L}$. Removal of total solids was noted to be $74.00 \%$ pH 8 and dose $0.1 \mathrm{~g} / \mathrm{L}$. Chloride reduction was observed to be about $93-94 \%$ at $\mathrm{pH}$ and dose ranges. Total hardness removal was negative, going to be a maximum of $20.14 \%$ at $\mathrm{pH} 7$ with $0.1 \mathrm{~g} / \mathrm{L}$, while calcium hardness was maximum at $76.92 \%$ at $\mathrm{pH} 8$ with $0.05 \mathrm{~g} / \mathrm{L}$ and $0.1 \mathrm{~g} / \mathrm{L}$.
Total nitrogen removal was maximum of $81.73 \%$ at $\mathrm{pH} 7$ with $0.05 \mathrm{~g} / \mathrm{L}$, and phosphorous removal was the highest compared to the other sample's maximum up to $78 \%$.

\section{Parameter-wise comparison between coagulants}

Turbidity reduction of aquaculture wastewaters by coagulants was observed to be least with a blended coagulant, which was negative, and highest was observed with ferric chloride coagulant at $\mathrm{pH} 7(86.96 \%)$ (Fig. 1). Electrical conductivity reduction of aquaculture wastewaters by coagulants was observed to be least with seeds of MO-chitin $(0.74 \%)$, and highest was observed with ferric chloride at pH 8 (99.81\%) (Fig. 2).

Total dissolved solids reduction of aquaculture wastewaters by the coagulant was observed to be least with MO
Table 4 Percentage reduction in physicochemical parameters after treating with Moringa oleifera seeds (MO)

\begin{tabular}{llllllllll}
\hline pH & Dose & Turbidity & EC & $\begin{array}{l}\text { Total } \\
\text { dissolved } \\
\text { solids }\end{array}$ & Chlorides & Total hardness & Calcium hardness & TN & TP \\
\hline 6 & 0.05 & -21.74 & 0.74 & -10.70 & 80.21 & -36.84 & 76.92 & 37.39 & 29.09 \\
& 0.1 & 4.35 & 4.55 & -6.47 & 81.25 & -26.32 & 76.92 & 40 & 40 \\
& 0.15 & -13.04 & 1.51 & -9.86 & 82.29 & -42.11 & 61.54 & 38.26 & 50.90 \\
& 0.2 & -8.70 & 5.24 & -5.65 & 78.13 & -47.37 & 69.23 & 41.73 & 52.72 \\
7 & 0.05 & -4.35 & 2.05 & -9.26 & 92.71 & -15.79 & 76.92 & 37.39 & 53.63 \\
& 0.1 & -21.74 & 0.74 & -10.70 & 81.25 & -15.79 & 84.62 & 40 & 52.72 \\
& 0.15 & 17.39 & 2.05 & -9.26 & 83.33 & 0.00 & 76.92 & 44.34 & 55.45 \\
& 0.2 & 30.43 & 2.05 & -9.26 & 79.17 & -42.11 & 84.62 & 46.95 & 55.45 \\
8 & 0.05 & 34.78 & 5.33 & -5.61 & 80.21 & -5.26 & 76.92 & 48.69 & 65.45 \\
& 0.1 & 43.48 & 3.32 & -7.84 & 83.33 & 0.00 & 76.92 & 46.95 & 69.09 \\
& 0.15 & 30.43 & 4.55 & -6.47 & 83.33 & -36.84 & 76.92 & 49.56 & 64.54 \\
& 0.2 & 47.83 & 5.77 & -5.10 & 80.21 & -15.79 & 76.92 & 50.43 & 67.27 \\
\hline
\end{tabular}

Table 5 Percentage reduction in physicochemical parameters after treating with $\mathrm{MO}+$ chitin

\begin{tabular}{llrlllllll}
\hline pH & Dose & Turbidity & EC & $\begin{array}{l}\text { Total } \\
\text { dissolved } \\
\text { solids }\end{array}$ & Chlorides & Total hardness & Calcium hardness & TN & TP \\
\hline 6 & 0.05 & 21.74 & 29.71 & 21.60 & 94.79 & -10.53 & 61.54 & 73.04 & 74.54 \\
& 0.1 & -17.39 & 27.50 & 19.12 & 94.79 & -15.79 & 69.23 & 74.78 & 76.36 \\
& 0.15 & -26.09 & 35.67 & 28.24 & 94.79 & -5.26 & 61.54 & 77.39 & 78.18 \\
& 0.2 & -65.22 & 28.98 & 20.78 & 94.79 & -21.05 & 61.54 & 79.13 & 78.18 \\
7 & 0.05 & 39.13 & 27.44 & 19.12 & 93.75 & -15.79 & 69.23 & 81.73 & 73.63 \\
& 0.1 & -13.04 & 63.75 & 70.29 & 95.83 & -26.32 & 53.85 & 80.86 & 73.63 \\
& 0.15 & -52.17 & 34.72 & 19.97 & 94.79 & -26.32 & 61.54 & 81.70 & 78.18 \\
& 0.2 & -52.17 & 64.13 & 23.94 & 95.83 & -31.58 & 69.23 & 80 & 78.18 \\
8 & 0.05 & 56.52 & 33.78 & 26.15 & 94.79 & -10.53 & 76.92 & 73.04 & 74.54 \\
& 0.1 & 0.00 & 64.49 & 74.00 & 94.79 & -57.89 & 76.92 & 71.30 & 70.90 \\
& 0.15 & -43.48 & 32.47 & 24.68 & 93.75 & -21.05 & 61.54 & 72.17 & 71.81 \\
& 0.2 & -21.74 & 31.11 & 23.17 & 93.75 & -26.32 & 69.23 & 72.17 & 71.81 \\
\hline
\end{tabular}


seeds that were negative and highest observed with ferric chloride at $\mathrm{pH} 8$ with all doses (55.98\%) (Fig. 3). Chloride reduction of aquaculture wastewaters by the coagulant was observed to be least with ferric chloride $(36.46 \%)$, and the highest was observed with blended coagulant at all $\mathrm{pH}$ and dose ranges (94-95\%) (Fig. 4).

Total hardness reduction was negative by all the coagulants (Fig. 5) except chitin which was highest with chitin at $\mathrm{pH} 7$, dose 0.15 , and $0.20(84.2 \%)$. Calcium hardness reduction of aquaculture wastewaters by the coagulant was observed to be least with chitin, and highest was observed with M. oleifera at pH 7, dose 0.1 and 0.2 (84.6\%) (Fig. 6).

Total nitrogen reduction of aquaculture wastewaters by the coagulant was observed at least with ferric chloride (18.2) at $7 \mathrm{pH}$ with a dose of 0.1 . The highest was observed with MO-chitin at pH 7 with doses 0.05 and 0.15 (Fig. 7). Total phosphorous reduction of aquaculture wastewaters by three coagulants was observed to be least with ferric chloride $(16.36 \%)$, and the highest was observed with blended coagulant at all $\mathrm{pH}$ and dose ranges (70.90-78.18\%) (Fig. 8).

\section{FTIR analysis}

FTIR instrument was used to analyze the MO-chitin sample (Fig. 9) near the IR region. The blended powder was strained by $75-\mu$ sieve and mixed with the $\mathrm{KBr}$ and compressed and pelletized to a volume of $1 / 100 \mathrm{~W} / \mathrm{W}$ and used for the analysis. The adsorption peak for MO-chitin was found at $1373 \mathrm{~cm}^{-1}$ representing $\mathrm{C}-\mathrm{H}$ of the alkali group with bend structures. The peak at $1586 \mathrm{~cm}^{-1}$ indicated aromatic compounds, and $1646 \mathrm{~cm}^{-1}$ indicated the presence of N-H groups' bend structures. Further $1703,1740 \mathrm{~cm}^{-1}$ showed that the samples consisted of carboxylic aldehyde groups are responsible for the adsorption phenomenonthe peaks at 2922 and $3676 \mathrm{~cm}^{-1}$ attributed to the presence of carboxylic and aromatic compounds. The colloidal particles' adsorption onto the MO-chitin surface is due to the interaction of charges by the hydrogen bonds of carboxylic and alkali groups (Saritha et al. 2019; Araújo et al. 2010; Espíndola-Cortés et al. 2017). The polymer adsorbed might be stabilized or altered depending on the presence of the number of particles and polymers and their affinity toward water-polymer-particles adsorption (Saritha et al. 2019).

\section{XRD analysis}

XRD patterns of the MO-chitin are shown in Fig. 10. The XRD patterns revealed that these materials have amorphous and small crystalline regions (da Silva Lucas et al. 2021;

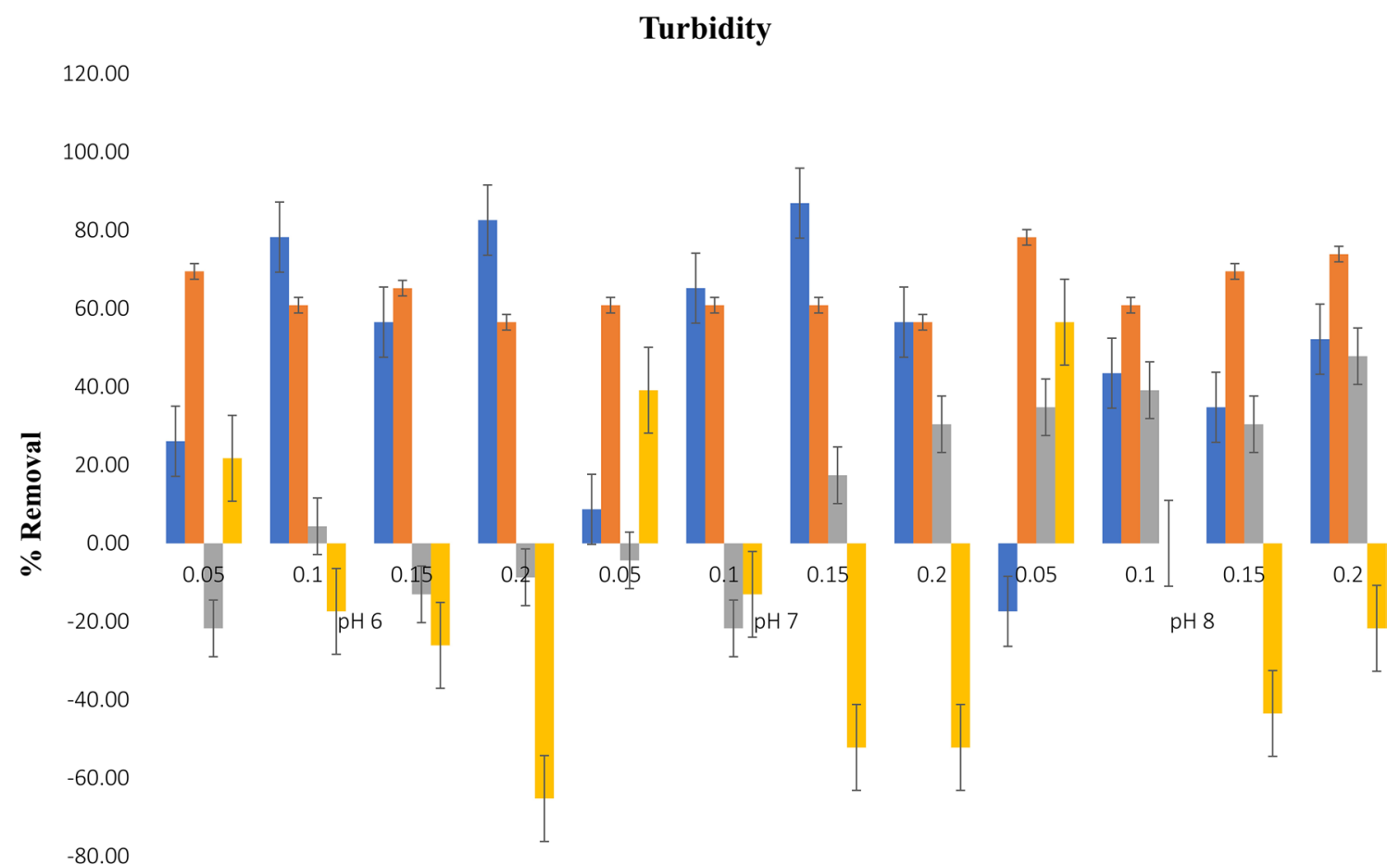

$-100.00$

$\square \mathrm{FeCl} \square$ Chitin $\square \mathrm{MO} \square \mathrm{MO}+$ Chitin

Fig. 1 Turbidity comparison of the coagulants 


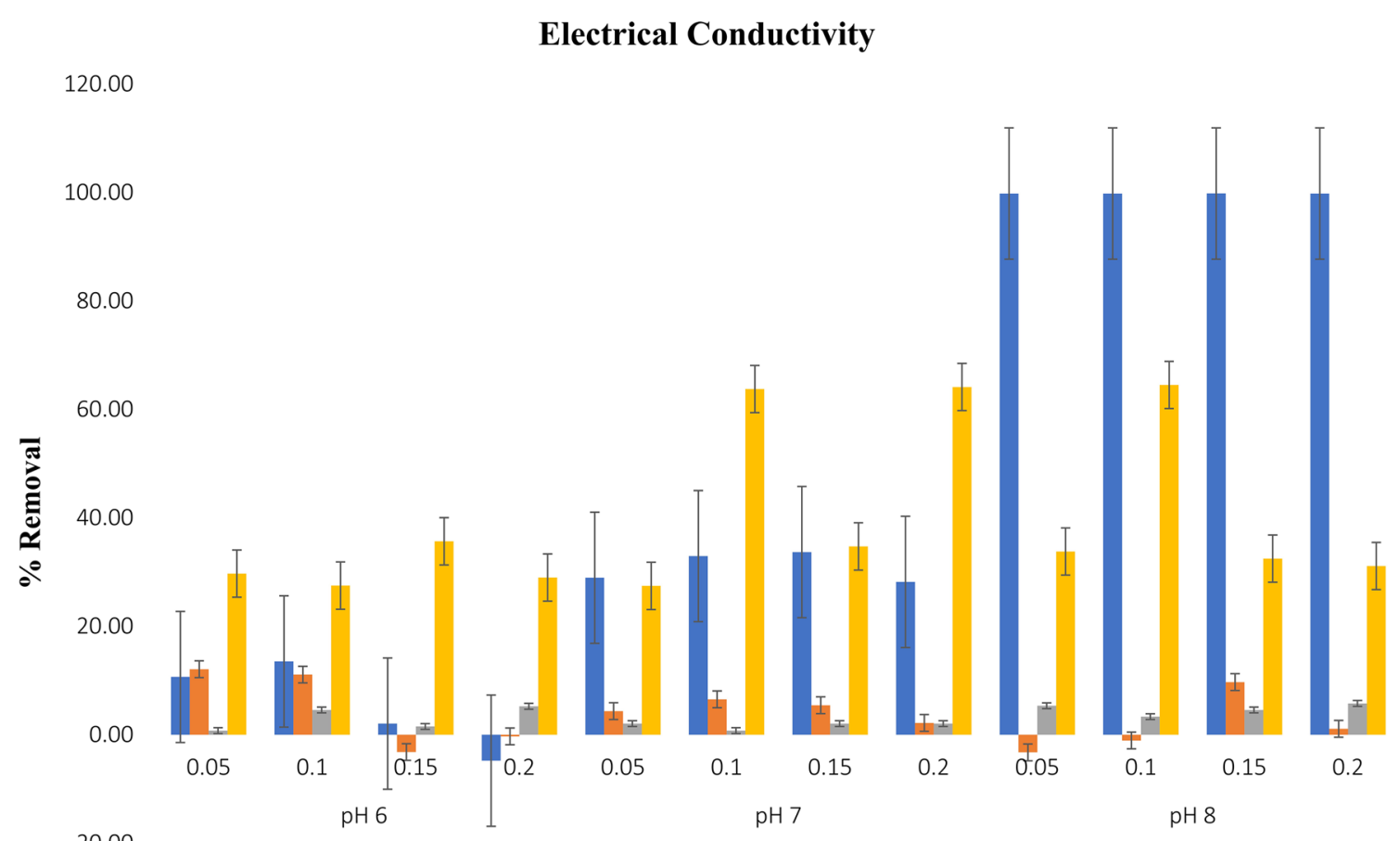

$-20.00$

$-40.00$

aeCl3 $\quad$ Chitin $\quad \mathrm{MO} \square \mathrm{MO}+$ Chitin

Fig. 2 Electrical conductivity reduction by the coagulants

Aleman-Ramirez et al. 2021). XRD patterns explain whether the prepared compounds do not have any impurities and are in pristine forms. In general, the peaks reflect the conditions and effects of the experiments denoting smaller particles size. The MO-chitin offered the reflections in a 2-theta range of 10-90. Intensive peaks are observed at 50.53, 40.83, 38.57, 36.32, $30.44,28.71,24.70$, and 15.35 , indicating the compounds' crystallinity and amorphous nature. These features might be responsible for the adsorption of pollutants onto the coagulant surface (Aleman-Ramirez et al. 2021).

\section{SEM analysis}

SEM analysis of MO-chitin showed (Fig. 11) the firm and dense structure with a heterogeneous and microscopic porous matrix, indicating that all the impurities are adsorbed onto the compound's surface, which might be attributed to the presence of moieties of proteins. Thus, from these features, it is evident that these compounds have enough morphological profile for adsorbing other impurities.

\section{Microbial analysis}

$\mathrm{H}_{2} \mathrm{~S}$ bottles were used to test the microbial contamination in wastewater, and Fig. 12 shows (a) E. coli, (b) Vibrio, (c)
Salmonella in the effluents. However, after treating the sample with MO-chitin coagulants, the microbes were removed entirely from the water samples.

\section{Discussion}

Wastewaters emanating from aquaculture ponds possess typical characteristics like more significant pollutant load in organic matter, nutrients, solids, and salts, causing high turbidity. The turbidity encompasses plankton, clay particles, feces, detritus along with the waste feed. If these solids are removed, recycling these waters is possible. Moreover, as the options for recycling increase, the pollution of water bodies reduces. In these lines, the present study utilized the natural coagulants chitin and seeds of $M$. oleifera to treat aquaculture wastewaters, compared the efficiency of $M$. oleifera to that of ferric chloride, and used a blend of coagulants, i.e., $\mathrm{MO}+$ Chitin (Moringa oleifera + chitin). The pathway of chitosan coagulation primarily depends on the deacetylation and $\mathrm{pH}$ of the wastewater. It has been shown that the greater the deacetylation, the lesser the $\mathrm{pH}$ enhanced, which is the performance of chitosan (Wang et al. 2021). Though not in acetylated form, chitin in the present study showed better efficacy in its blended form removing 94-95\% of chloride. 


\section{Total Dissolved Solids}

100.00

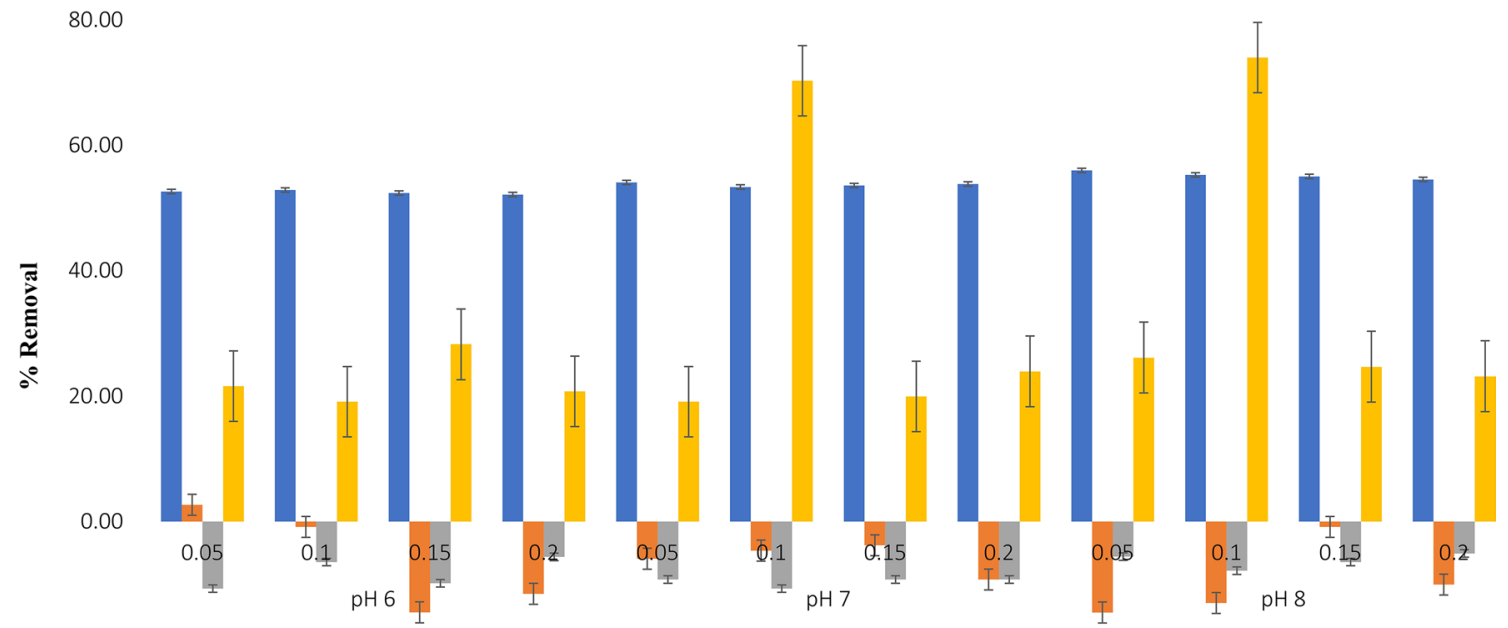

$-20.00$

$-40.00$

Fig. 3 Total dissolved solids reduction by the coagulants

- FeCl3 $\square$ Chitin $=\mathrm{MO}=\mathrm{MO}+$ Chitin

\section{Chlorides}

120.00

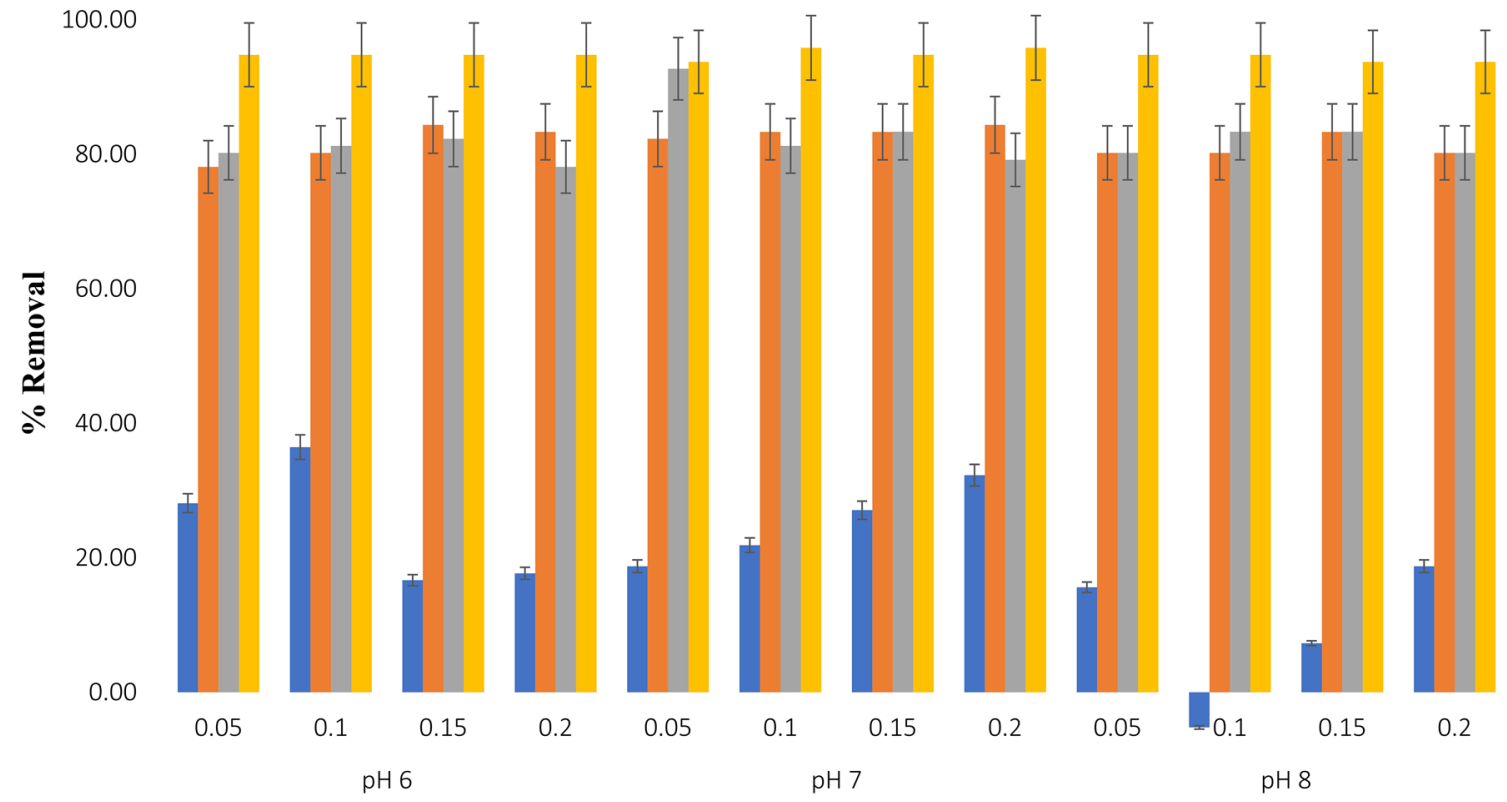

$-20.00$

- FeCl3 Chitin $\quad \mathrm{MO}=\mathrm{MO}+$ Chitin

Fig. 4 Chloride reduction by the coagulants 


\section{Total hardness}

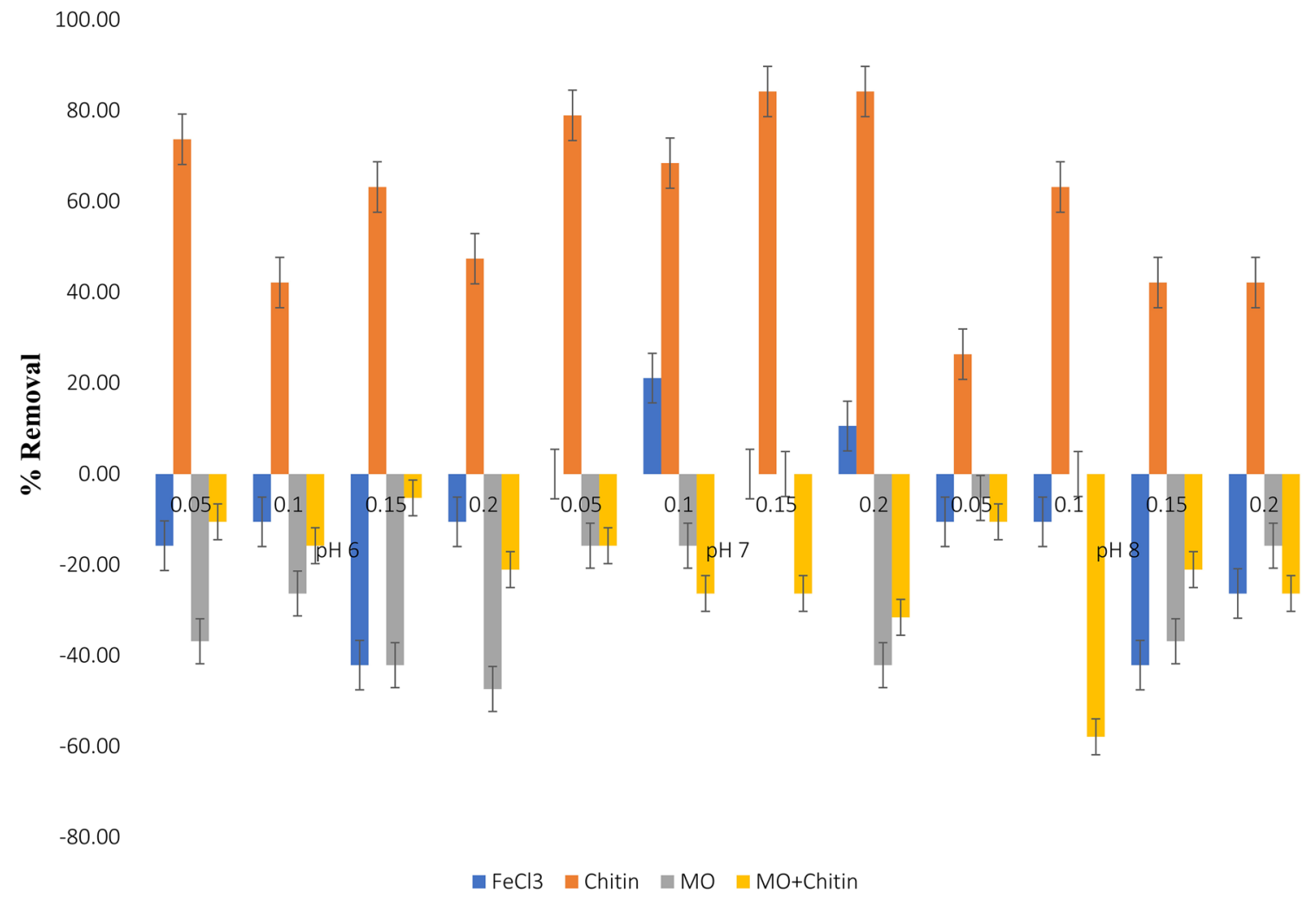

Fig. 5 Total hardness reduction by the coagulants

$50 \%$ reduction in TDS was obtained by ferric chloride in the present study. Vijayasri et al. (2013) presented a decrease in COD from initial 102 to final $5.31 \mathrm{mg} / \mathrm{L}$ post-treatment with ferric chloride along with the culture of microalgae. This is similar to the results in the present study, where only ferric chloride was not effective in removing pollutant parameters. A noteworthy point was regarding the sturdy flocs formed by ferric coagulant containing $\mathrm{Fe}(\mathrm{OH})_{3}$ with higher density than the flocs created by the organic coagulants in the study (Ebeling et al. 2003).

TDS reduction and turbidity reduction from the aquaculture wastewaters are presented in Figs. 1, and 3, which illustrates the dosage of coagulants governs disparities of TDS and turbidity in wastewaters. The results are in acceptance with the earlier studies (Ebeling et al. 2003). As dosage increased, the TDS and turbidity removal were enhanced by $\mathrm{FeCl}_{3}$ while they diminished swiftly beyond above a dosage of $0.15 \mathrm{~g} / \mathrm{L}$ for $\mathrm{MO}$ and blended coagulant. It is inferred from the results that $\mathrm{FeCl}_{3}$ was much efficient in removing TDS and turbidity from the test waters are due to the reduction of solubility of $\mathrm{Fe}(\mathrm{OH})_{3}$ at high ionic strength (Zhang et al. 2014), results in a lowering the aqueous double-layer thickness among majority solution and floc of the surface (Zhang et al. 2014).
Total hardness is a measure of the concentration of all metal cations except for alkali metals. Much of the concern about hardness in water treatment is with all the ions involved; in aquaculture, the problem is mainly calcium and magnesium concentration. Among various divalent salts, however, calcium and magnesium are understood to be the broader sources of water hardness. Another essential aspect of hardness is its effect on $\mathrm{pH}$ - soft water has low $\mathrm{pH}$, and hard water has high $\mathrm{pH}$. A desirable range would be between 75 and $200 \mathrm{mg} / \mathrm{L} \mathrm{CaCO}_{3}$. A low level of hardness $\left(10-20 \mathrm{mg} / \mathrm{L} \mathrm{CaCO}_{3}\right.$ ) can cause stress to animals. A high level of hardness is not desirable as it increases the $\mathrm{pH}$ and reduces other nutrients' availability. An essential impact of hardness on aquatic life is the effect of metals as cadmium, lead, chromium, and zinc. The toxicity of these metals decreases with hardness as they form insoluble precipitates and settle at the bottom and become unavailable to the aquatic organisms.

The lower levels of $\left.\mathrm{CaCO}_{3}(<100 \mathrm{mg} / \mathrm{L})\right)$ hardness present a consistent sign of a lower concentration of calcium. While greater hardness is necessary which may not be due to a greater calcium concentration, it can also be due to high magnesium concentrations with or without calcium. In the current study, the removal of calcium hardness was 


\section{Calcium hardness}

\section{0}

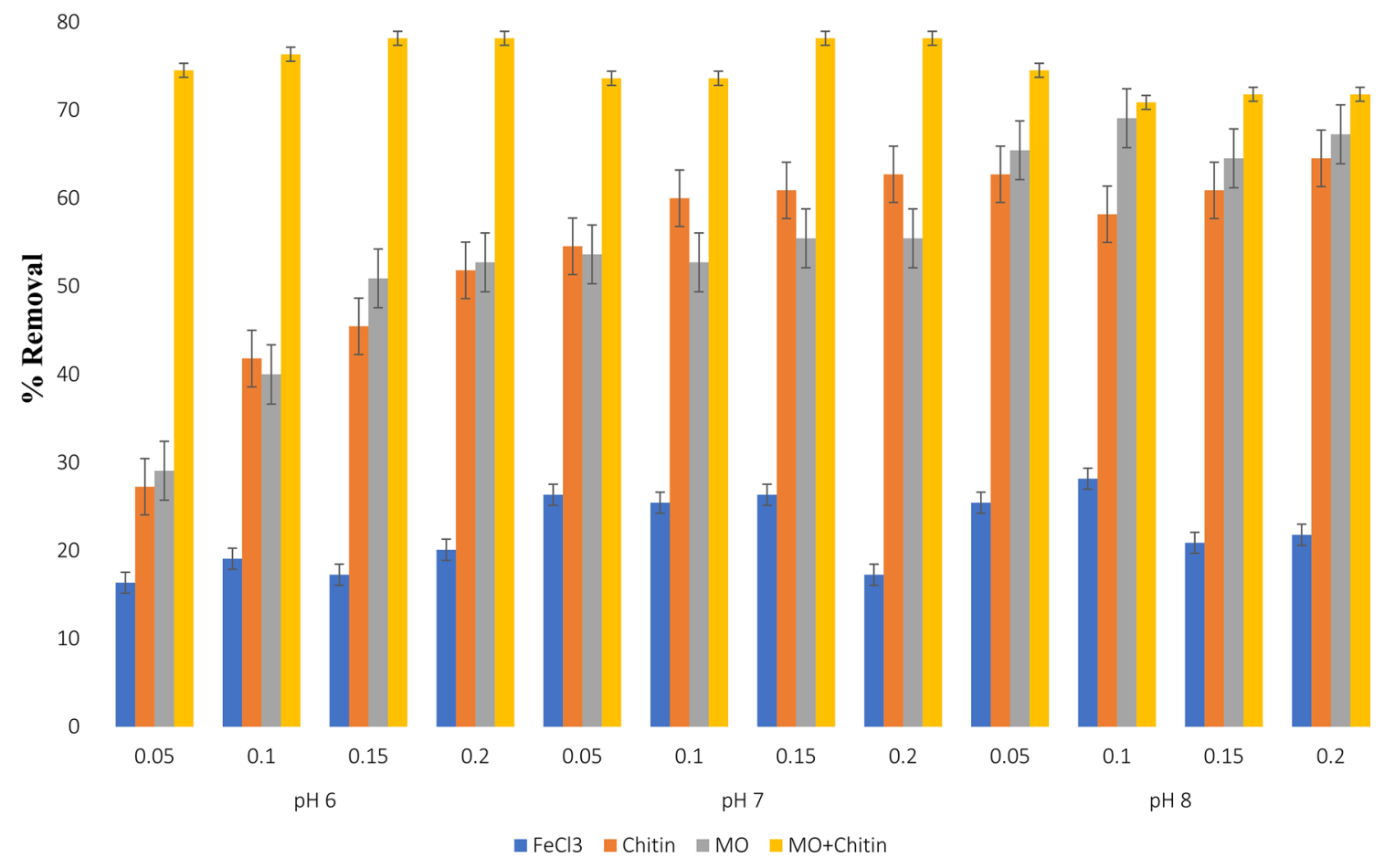

Fig. 6 Calcium hardness reduction by the coagulants

found to be a maximum of $84.62 \%$ by MO. In comparison, overall test coagulants efficiently removed more than $60 \%$ of calcium, essential enough for the shrimp growth. Total hardness is a necessary nutrient in shrimp farming —calcium ions minimize the rise of $\mathrm{pH}$ during the high photosynthetic rates. These ions are essential for bone formation; the crustaceans' shell formation in the brackish water aquaculture hardness by calcium ranges from 346 to 896.5 was observed. A review by Aarø (2020) stated that the natural coagulants $M$. oleifera and chitosan can compete with inorganic coagulants toward water treatment and that both coagulants have a greater affinity toward the removal of pollutants in water which includes organic molecules, inorganic ions through mechanisms like charge neutralization, bridging and electrostatic patch mechanism.

Precisely, while treating aquaculture water with dissolved organic carbon in terms of humic acids, charge neutralization and precipitation are dominant mechanisms of the coagulation process. Metal salts usually have more excellent neutralization capability over organic polymers, and hence, the efficiency of inorganic coagulants for treatment of these wastewaters is supposed to be high (Heiderscheidt et al. 2016; Sillanpää et al. 2018). Moreover, it is understood that the production of insoluble compounds from metal salts tends to improve coagulation/flocculation by enhancing particles' availability in the suspension, increasing reaction kinetics leading to floc aggregation (Heiderscheidt et al. 2020; Sun et al. 2019).

Heiderscheidt et al. 2020 have reported stable and effective removal of phosphorus from the sludge obtained from aquaculture wastewater using coagulation by inorganic salts. While Zadinelo et al. (2018) said greater efficiency in removing ammonia from aquaculture wastewater upon coagulation with higher doses of chitosan foam, they have attributed to the enhanced surface area and adsorption sites coagulant. Higher concentrations of ammonia in the environment are problematic due to its toxicity, specifically to aquatic organisms, leading 
90

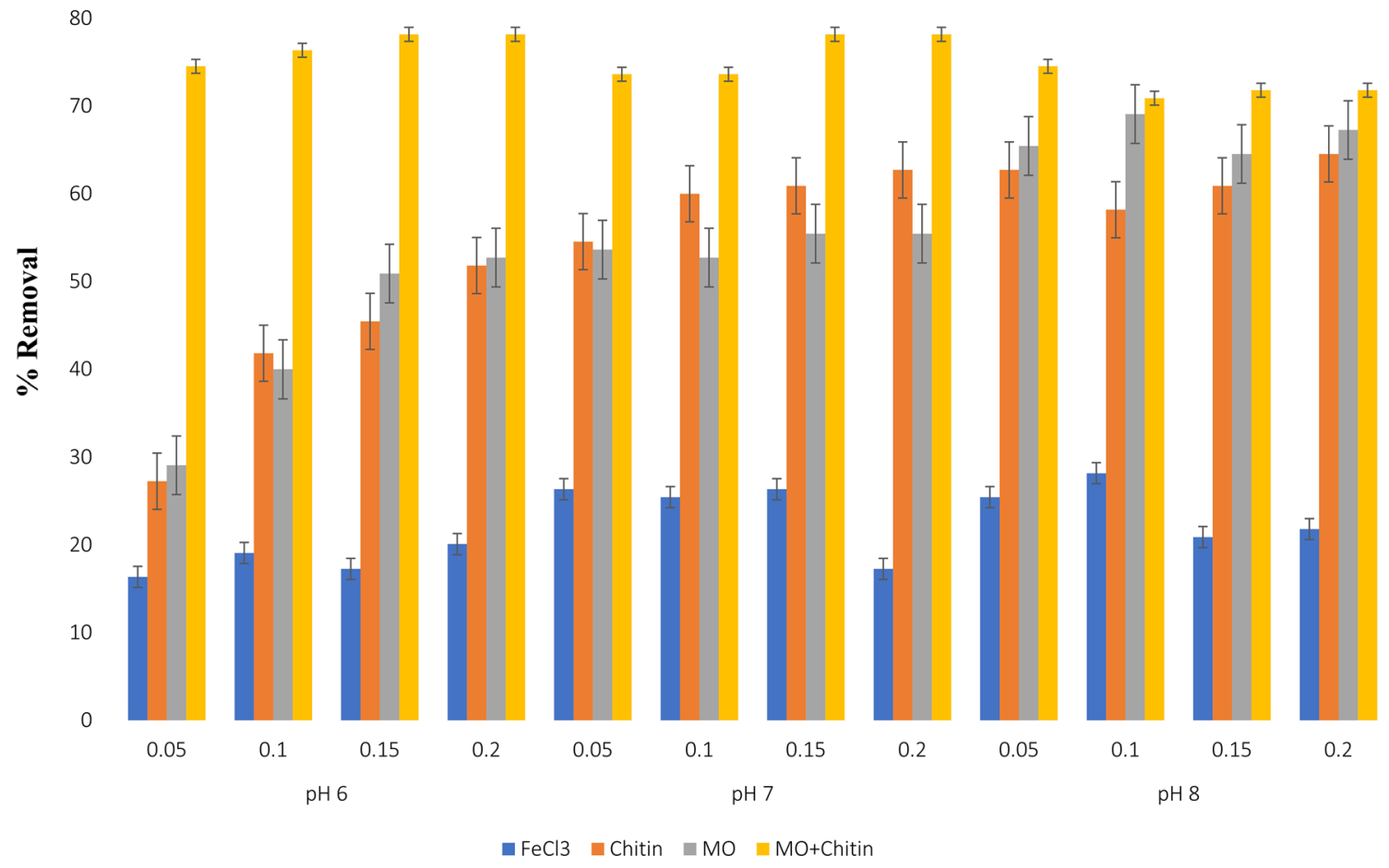

Fig. 7 Total nitrogen reduction by the coagulants

to ammonia concentrations and a cascade of intracellular reactions leading to mortality (Haseena et al. 2016). Owing to the biodegradable nature of chitosan and ammonia removed being a nutrient, the sludge obtained can be used as fertilizer.

Effective and faster removal of dissolved orthophosphate was obtained during the interaction of protonates, the chitosan amino groups with phosphate ions in the medium (Zadinelo et al. 2018). The nitrate removal by chitosan foam up to $73 \%$ was reported attributed to the foremost mechanism of adsorption by chitosan and physical adsorption (intermolecular) due to van der Waals forces. The adsorption is governed by external factors like temperature, pH, etc. (Zadinelo et al. 2018; Karnena and Saritha 2021). Similar results were obtained by Chung (2006), wherein the concentrations of orthophosphate after treatment were found to be acceptable for discharge into natural waters.

\section{Conclusion}

The following conclusions are derived from the present study:
- Ferric chloride was effective in removing turbidity of the wastewater $(86.96 \%)$ along with $52.55 \%$ of total dissolved solids in all ranges of $\mathrm{pH}$ and dose.

- Chitin proved to be effective in removing turbidity (78.2\%), chloride (84\%), hardness (84.21\%), total nitrogen (53.04\%), and total phosphorus (64.84\%).

- Moringa oleifera has effectively reduced chloride to $92.71 \%$, with total nitrogen and total phosphorus removal rates at $50.43 \%$ and $69.09 \%$.

- The di-blend of Moringa oleifera and chitin resulted in a $66.49 \%$ reduction in electrical conductivity, $74 \%$ reduction in total dissolved solids, $95 \%$ reduction of chloride, $81.70 \%$ removal of total nitrogen, and $78.18 \%$ removal of the total phosphorus.

Overall, di-blend adopted and tested in the study has proved to be promising and very effective in removing various physicochemical parameters that result in causing pollution. Further, the characterization studies carried out on the di-blend coagulant has revealed and proved its coagulation efficacy. FTIR analysis revealed the functional groups that were responsible for the process of coagulation in the di-blend. XRD analysis provided the input of the 


\section{Total Phosphorus}

90

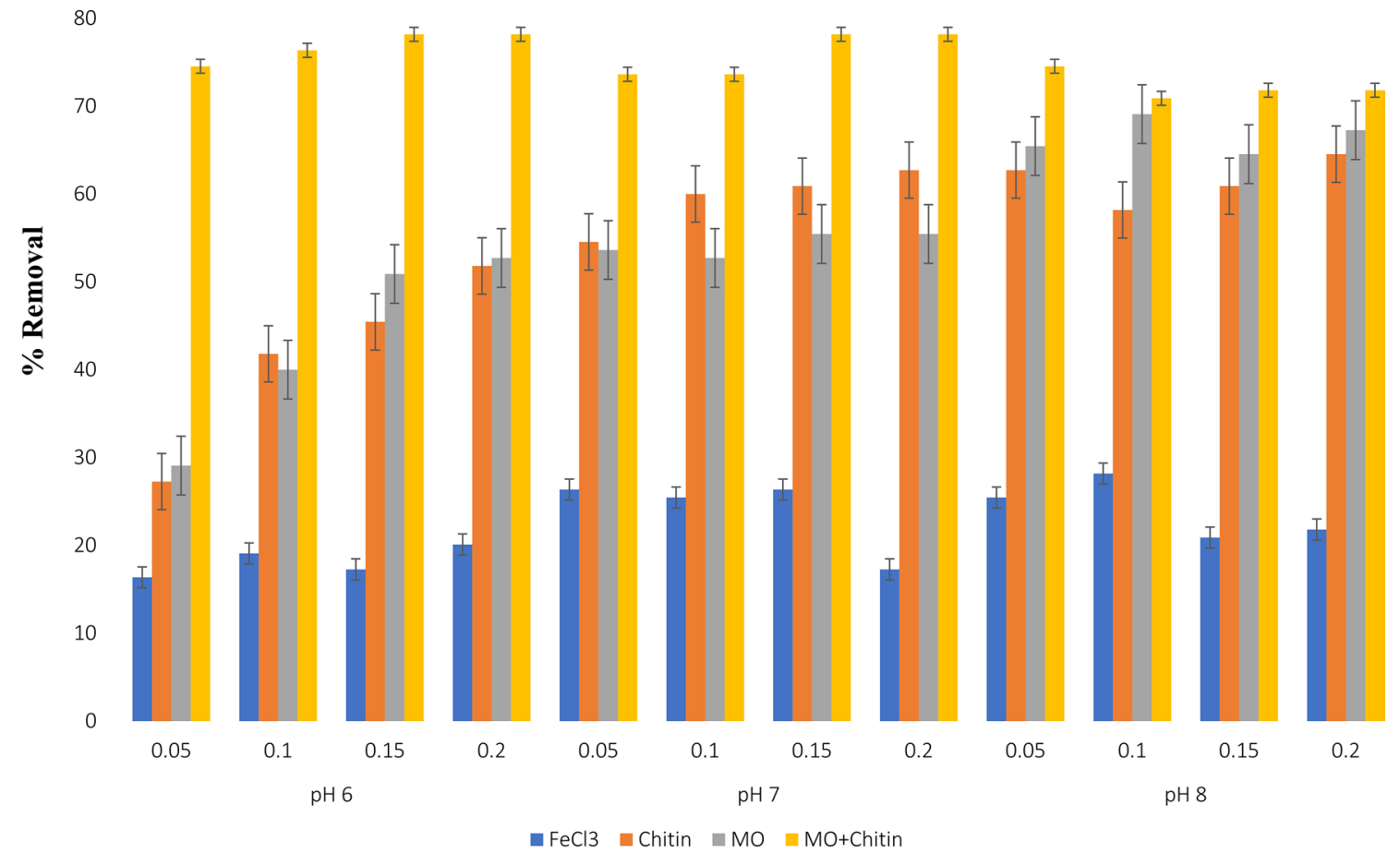

Fig. 8 Total phosphorus reduction by the coagulants

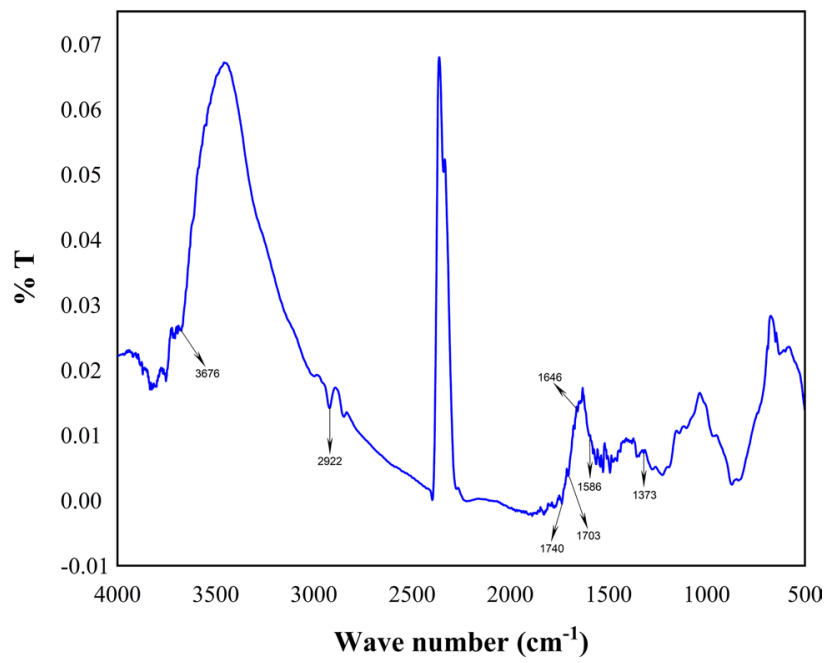

Fig. 9 FTIR analysis of the coagulant (MO-chitin)

coagulant being crystalline in nature which would have provided a greater surface area for adsorption. Finally, SEM images have confirmed the sturdy nature of the floc

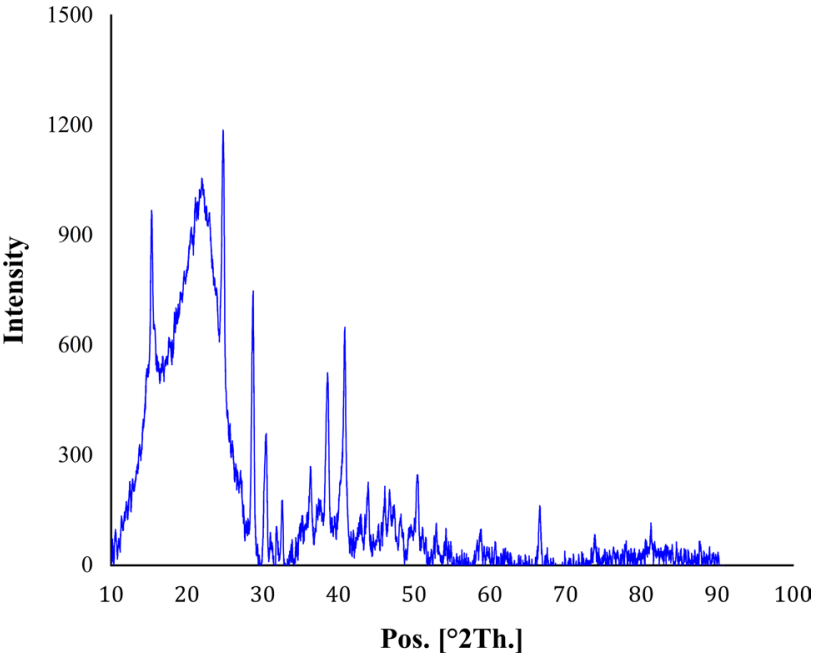

Fig. $10 \mathrm{XRD}$ analysis of the coagulant (MO-chitin)

formed on the coagulant. With these observations from the study, it is concluded that natural coagulants are equally competent for the removal of pollution parameters, with 


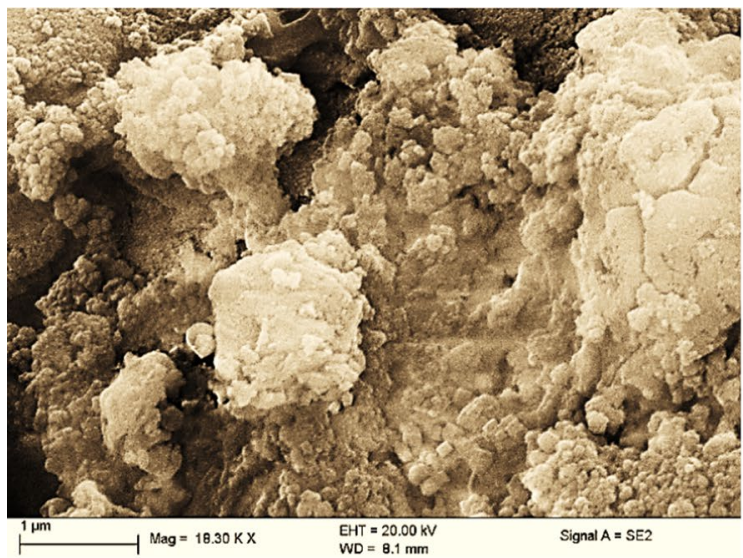

(a)

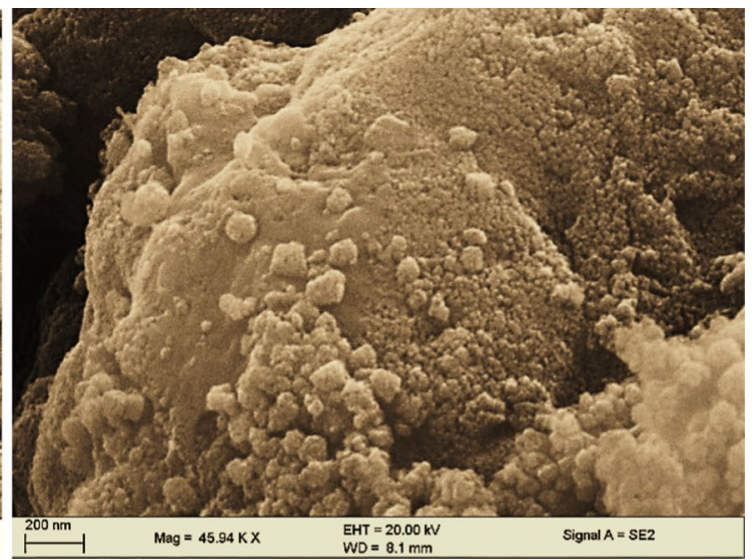

(b)

Fig. 11 a Magnified view of MO-chitin at $18 \mathrm{KX}$. b Magnified view of MO-chitin at $45 \mathrm{KX}$

Fig. 12 Microbial analysis before treatment $(\mathbf{a}-\mathbf{c})$ and after treatment (d) with $\mathrm{MO}-$ chitin

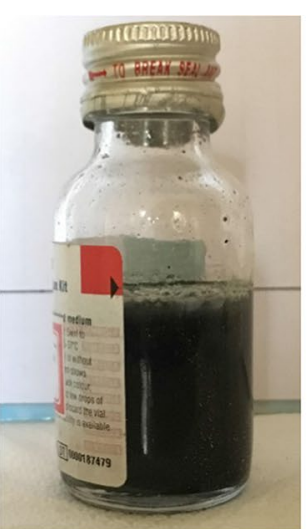

(a)

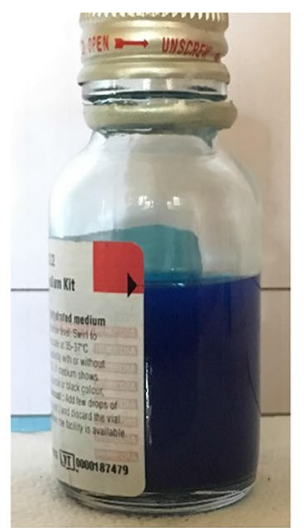

(b)

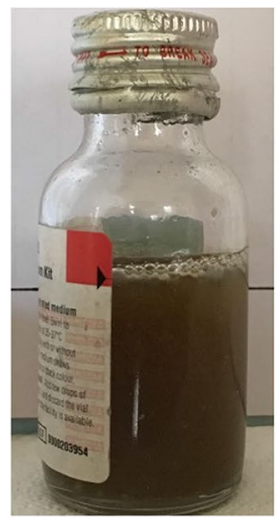

(c)

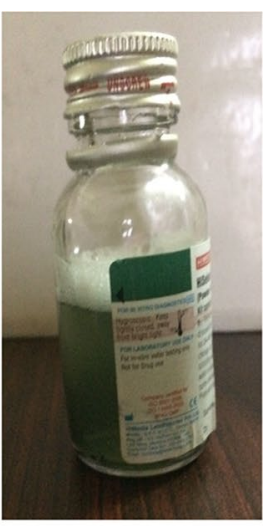

(d) blended coagulants offering promising solutions. Hence, further studies will be aimed at the preparation and application of these coagulants at a large scale with possible commercialization.

\section{Acknowledgements None.}

Author's contribution All the authors contributed equally to the manuscript.

Funding The authors received no specific funding for this work.

\section{Declarations}

Conflict of interest The authors declare that they have no conflict of interest.

Human and animal rights This article does not contain any studies involving animals performed by any of the authors.
Open Access This article is licensed under a Creative Commons Attribution 4.0 International License, which permits use, sharing, adaptation, distribution and reproduction in any medium or format, as long as you give appropriate credit to the original author(s) and the source, provide a link to the Creative Commons licence, and indicate if changes were made. The images or other third party material in this article are included in the article's Creative Commons licence, unless indicated otherwise in a credit line to the material. If material is not included in the article's Creative Commons licence and your intended use is not permitted by statutory regulation or exceeds the permitted use, you will need to obtain permission directly from the copyright holder. To view a copy of this licence, visit http://creativecommons.org/licenses/by/4.0/.

\section{References}

Aarø SS (2020) A review of selected natural coagulants in water and wastewater treatment. Master's thesis, Norwegian University of Life Sciences, Ås

Aleman-Ramirez JL, Moreira J, Torres-Arellano S, Longoria A, Okoye PU, Sebastian PJ (2021) Preparation of a heterogeneous 
catalyst from moringa leaves as a sustainable precursor for biodiesel production. Fuel 284:118983

Alishahi A, Aïder M (2012) Applications of chitosan in the seafood industry and aquaculture: a review. Food Bioproc Technol 5(3):817-830

Araújo CS, Alves VN, Rezende HC, Almeida IL, De Assuncao R, Tarley CR, Segatelli MG, Coelho NM (2010) Characterization and use of Moringa oleifera seeds as biosorbent for removing metal ions from aqueous effluents. Water Sci Technol 62(9):2198-2203

Chung YC (2006) Improvement of aquaculture wastewater using chitosan of different degrees of deacetylation. Environ Technol 27(11):1199-1208

da Silva Lucas AJ, Oreste EQ, Costa HLG, López HM, Saad CDM, Prentice C (2021) Extraction, physicochemical characterization, and morphological properties of chitin and chitosan from cuticles of edible insects. Food Chem 343:128550

Dhanke P, Wagh S, Patil A (2019) Treatment of fish processing industry wastewater using hydrodynamic cavitational reactor with biodegradability improvement. Water Sci Technol 80(12):2310-2319

Ebeling JM, Sibrell PL, Ogden SR, Summerfelt ST (2003) Evaluation of chemical coagulation-flocculation aids for the removal of suspended solids and phosphorus from intensive recirculating aquaculture effluent discharge. Aquac Eng 29(1-2):23-42

Espíndola-Cortés A, Moreno-Tovar R, Bucio L, Gimeno M, RuvalcabaSil JL, Shirai K (2017) Hydroxyapatite crystallization in shrimp cephalothorax wastes during subcritical water treatment for chitin extraction. Carbohydr Polym 172:332-341

Haseena PV, Padmavathy KS, Krishnan PR, Madhu G (2016) Adsorption of ammonium nitrogen from aqueous systems using chitosanbentonite film composite. Proc Technol 24:733-740

Heiderscheidt E, Leiviskä T, Ronkanen AK, Kløve B (2016) Evaluating the suitability of synthetic organic polymers to replace iron salts in the purification of humic and sediment-rich runoff. Desalin Water Treat 57(23): 10948-10957

Heiderscheidt E, Tesfamariam A, Pulkkinen J, Vielma J, Ronkanen AK (2020) Solids management in freshwater-recirculating aquaculture systems: effectivity of inorganic and organic coagulants and the impact of operating parameters. Sci Total Environ 742:140398

Joseph SM, Krishnamoorthy S, Paranthaman R, Moses JA, Anandharamakrishnan C (2021) A review on source-specific chemistry, functionality, and applications of chitin and chitosan. Carbohydr Polym 2:100036

Karnena MK, Saritha V (2020) Natural resources for sustainable water treatment: a review. Curr Environ Manag 7(1):36-54

Karnena MK, Saritha V (2021) Natural coagulants for the treatment of water and wastewater: a futuristic option for sustainable water clarification. Recent Innov Chem Eng 14(2):120-147

Kritchenkov AS, Kletskov AV, Egorov AR, Tskhovrebov AG, Kurliuk AV, Zhaliazniak NV, Shakola TV, Khrustalev VN (2021) New water-soluble chitin derivative with high antibacterial properties for potential application in active food coatings. Food Chem 343:128696

Lin YM, Liu Y, Tay JH (2003) Development and characteristics of phosphorus-accumulating microbial granules in sequencing batch reactors. Appl Microbiol Biotechnol 62(4):430-435

Ngatia L, Grace III JM, Moriasi D, Taylor R (2019) Nitrogen and phosphorus eutrophication in marine ecosystems. Monit Mar Pollut $1-17$

Rotter A, Barbier M, Bertoni F, Bones AM, Cancela ML, Carlsson J, Carvalho MF, Cegłowska M, Chirivella-Martorell J, Conk Dalay M, Cueto M (2021) The essentials of marine biotechnology. Front Mar Sci 8:158

Saritha V, Karnena MK, Dwarapureddi BK (2019) "Exploring natural coagulants as impending alternatives towards sustainable water clarification": a comparative studies of natural coagulants with alum. J. Water Process Eng 32:100982

Sillanpää M, Ncibi MC, Matilainen A, Vepsäläinen M (2018) Removal of natural organic matter in drinking water treatment by coagulation: a comprehensive review. Chemosphere 190:54-71

Sitek AJ (2020) Evaluating recirculating aquaculture system nutrient production, Doctoral dissertation, University of New Hampshire

Sun H, Jiao R, Xu H, An G, Wang D (2019) The influence of particle size and concentration combined with $\mathrm{pH}$ on coagulation mechanisms. J Environ Sci 82:39-46

Wang M, Bi S, Qin D, Su C, Wang H, Chen X (2021) Quantitative evaluation of the antibacterial effectiveness and efficiency of chitosan considering the effect of neutralization. Carbohydr Polym 265:117918

Yang R, Li H, Huang M, Yang H, Li A (2016) A review on chitosanbased flocculants and their applications in water treatment. Water Res 95:59-89

Yerlikaya P, Tokay FG, Alp AC, Cilay S (2021) Effect of shrimp fortification level on nutritional value, cooking quality and microstructure of freeze-dried noodles. Acta Alimentaria

Zadinelo IV, Dos Santos LD, Cagol L, de Muniz GIB, Ellendersen LDSN, Alves HJ, Bombardelli RA (2018) Adsorption of aquaculture pollutants using a sustainable biopolymer. Environ Sci Pollut Res 25(5):4361-4370

Zhang X, Hu J, Spanjers H, van Lier JB (2014) Performance of inorganic coagulants in treatment of backwash waters from a brackish aquaculture recirculation system and digestibility of salty sludge. Aquac Eng 61:9-16

Zhou X (2017) An overview of recently published global aquaculture statistics. FAO Aquac Newsletter 56:6

Publisher's Note Springer Nature remains neutral with regard to jurisdictional claims in published maps and institutional affiliations. 